\title{
Analisis Deiksis dalam Drama Seri Hotaru no Hikari II: Kajian Pragmatik
}

\author{
${ }^{1}$ Asteria Permata $\mathrm{M},{ }^{2}$ Titien Rostini \\ ${ }^{1,2}$ STBA YAPARI-ABA Bandung
}

\begin{abstract}
Pragmatic deixis research examines the element of speech in communication by considering contextual speech situations. In Japanese as one of the languages that recognize the honorific system, person deixis has an antecedent towards pronominal as a role or event in a language situation. Based on its type, there are three categories of person deixis namely first person person deixis, second person person deixis and third person person deixis. From the results of the analysis it was concluded that there were referents who moved or changed depending on the social status of the speaker and the speaker.
\end{abstract}

Keywords: Pragmatic Deixis, Honorific System, Japanese

Abstrak. Penelitian deiksis pragmatik mengkaji tentang unsur tuturan dalam komunikasi dengan mempertimbangkan situasi ujaran yang bersifat kontekstual. Pada bahasa Jepang sebagai salah satu bahasa yang mengenal sistem honorifik, deiksis persona beranteseden terhadap pronominal sebagai peran atau peristiwa dalam situasi bahasa. Berdasarkan jenisnya, terdapat tiga kategori deiksis persona yaitu deiksis persona orang pertama, deiksis persona orang kedua dan deiksis persona orang ketiga. Dari hasil analisis diperoleh kesimpulan adanya referen yang berpindah atau berubah tergantung status sosial penutur dan petuturnya.

\section{Kata Kunci: Deiksis Pragmatik, Sistem Honorifik, Bahasa Jepang}

\section{A. PENDAHULUAN}

Kajian pragmatik didasarkan pada prinsip kerjasama dan prinsip kesantunan berbahasa berdasarkan budaya dari masing-masing negara dengan mempertimbangkan situasi status sosial yang berbeda antara penutur dan petuturnya.

Karena itu, selain mempelajari bahasa Jepang secara gramatika, pembelajar bahasa Jepang pun perlu untuk mengetahui hal-hal lain yang berkenaan dengan etika berbahasa dalam bahasa Jepang berdasarkan status sosial penutur dan petuturnya. Hal ini dapat dilakukan dengan mengamati unsur-unsur komunikasi dalam bahasa. Salah satu unsur komunikasi ujaran yang cukup menarik untuk diamati adalah deiksis.
Deiksis selalu hadir baik dalam komunikasi sehari-hari maupun dalam suatu teks atau bacaan. Deiksis adalah bentuk bahasa yang berfungsi sebagai penunjuk hal atau fungsi tertentu di luar bahasa (Sudaryat, 200 8:121). Menurut Lyons (1977: 636), deiksis dipakai untuk menggambarkan fungsi pronomina persona, demonstratif, fungsi waktu, aneka gramatikal dan leksikal lainnya yang menghubungkan ujaran dengan jalinan ruang dan waktu dalam tindak ujaran.

Deiksis digunakan untuk mengetahui siapa penuturnya, siapa atau apa yang dimaksud dalam tuturan tersebut, dan kapan waktu dalam tuturan itu terjadi. Dengan kata lain, deiksis juga terikat dengan konteks kalimat untuk menentukan acuan rujukannya tersebut. 
Sesuatu yang diacu oleh deiksis disebut anteseden. Berdasarkan antesedennya, deiksis dibedakan atas enam macam yaitu: deiksis persona, deiksis temporal, deiksis lokatif, deiksis wacana, dan deiksis sosial (Levinson, 1978: 68-90).

Dari paparan tersebut, dapat kita ketahui bahwa pemahaman mengenai deiksis merupakan hal yang penting dimiliki oleh para pembelajar bahasa Jepang. Dari kenyataan tersebut muncul pertanyaan deiksis apa saja yang digunakan dalam percakapan bahasa Jepang.

\section{Tujuan dan Manfaat Penelitian}

Tujuan penelitian disusun sesuai dengan ruang lingkup masalah penelitian, yaitu mengkaji tentang deiksis persona yang terdapat pada Drama seri Hotaru no Hikari II episode I dan mendeskripsikan peran status sosial sebagai faktor penentu pemilihan penggunaan deiksis persona pada percakapan yang terdapat dalam drama seri Hotaru no Hikari II episode I. Hasil penelitian ini bermanfaat untuk menambah wawasan bagi para pemerhati linguistik bahasa Jepang di tingkat perguruan tinggi.

\section{Kajian Pustaka Pragmatik}

Purwo (1990 : 16) dan Leech (1983: 21) mendefinisikan pragmatik sebagai ilmu yang mengkaji makna tuturan, sedangkan semantik adalah ilmu yang mengkaji makna kalimat, pragmatik mengkaji makna dalam hubungannya dengan situasi ujar. Djajasudarma (1994: 56) menerangkan bahwa pragmatik mengkaji unsur makna ujaran yang tidak dapat dijelaskan melalui referensi langsung pada pengungkapan ujaran dan juga mencakup studi interaksi antara pengetahuan kebahasaan dan dasar pengetahuan tentang dunia yang dimiliki oleh pendengar / pembaca. Levinson (1983: 27) berpendapat bahwa pragmatik adalah kajian mengenai deiksis, implikatur, presuposisi, tindak tutur dan aspekaspek struktur wacana.

\section{Deiksis}

Kata deiksis berasal dari kata Yunani deiktikos, yang berarti hal penunjukkan secara langsung. Saragih (2006) mengatakan bahwa deiksis adalah sebagai unit linguistik (bunyi, kata, frase, klausa) dengan rujukan atau maknanya ditentukan oleh konteks dengan rujukan ke pemakai bahasa. Purwo (1984:1) mengatakan bahwa sebuah kata dikatakan deiksis apabila referennya berpindah-pindah atau berganti-ganti, tergantung pada siapa yang menjadi penutur dan petutur, tergantung pada saat dituturkan kata itu. Selanjutnya Alwi (1993) menjelaskan deiksis adalah gejala semantik yang hanya dapat ditafsirkan acuannya atau rujukannya dengan memperhitungkan situasi penutur.

\section{Jenis-jenis Deiksis}

Saragih (2003) membagi deiksis ke dalam lima jenis deiksis yaitu: deiksis personal, deiksis tempat, deiksis waktu, deiksis tekstual, dan deiksis sosial. Namun Levinson (1983: 62) menyatakan bahwa jenis deiksis terbagi atas tiga jenis deiksis yaitu deiksis personal, deiksis ruang, dan deiksis waktu. Sementara Saeed (2000) membagi deiksis ke dalam tiga jenis deiksis yaitu deiksis tempat, deiksis personal, dan deiksis sosial. Dengan demikian berarti jenis deiksis merupakan kategori tertentu dalam pembagian deiksis yang didasarkan pada sifat informasi yang terdapat pada deiksis.

\section{a. Deiksis Persona}

Deiksis personal merujuk atau menunjuk orang atau dengan kata lain deiksis personal adalah kata atau kelompok kata yang merujuk kepada pronominal sebagai peran atau 
peserta dalam peristiwa berbahasa. Ada tiga kategori peran yang biasa terlibat dalam peristiwa bahasa yaitu: a. Kategori persona pertama, b. Kategori persona kedua, c. Kategori persona ketiga (Cahyono, 1995:218).

1) Deiksis Persona Orang Pertama Deiksis persona pertama adalah kategorisasi rujukan penutur kepada diri sendiri.

2) Deiksis Persona Orang Kedua Kategori persona kedua adalah kategorisasi rujukan penutur dengan seseorang atau lebih pendengar.

\section{3) Deiksis Persona Orang Ketiga}

Kategori persona ketiga adalah kategorisasi rujukan penutur kepada orang atau benda yang bukan penutur atau pendengar.

\section{b. Deiksis Lokatif}

Deiksis lokatif atau tempat adalah pemberian bentuk kepada lokasi ruang dari lokasi penutur dalam peristiwa bahasa. Cahyono (1995) mengatakan bahwa deiksis tempat adalah pemberian bentuk pada lokasi menurut peserta dalam peristiwa bahasa.

Penutur menempati titik referensi, sesuatu yang dekat dengannya dideskripsikan dengan koko 'di sini', dan sesuatu yang jauh dari penutur dideskripsikan dengan soko, asoko 'di sana'. Disamping pembagian lokalisasi, penggunaannya harus dikalkulasi oleh partisipan pada konteks yang tepat tergantung pada konteks penutur/penulis. Deiksis yang terkait dengan kata kerja yang menunjuk suatu tempat seperti:'datang', 'pergi', 'membawa' dan sebagainya.

c. Deiksis Sosial

Deiksis sosial ialah rujukan yang dinyatakan berdasarkan perbedaan kemasyarakatan yang mempengaruhi peran penutur dan pendengar.
Perbedaan itu dapat ditunjukkan dalam pemilihan kata. Dalam beberapa bahasa, perbedaan tingkat sosial antara penutur dengan pendengar yang diwujudkan dalam seleksi kata dan frasa atau sistem morfologi kata-kata tertentu (Nababan, 1987: 42).

\section{B. METODE PENELITIAN}

Penelitian ini menggunakan metode deskriptif, dengan cara mendeskripsikan dan menginterpretasi data atau objek penelitian berdasarkan teori deiksis dan pragmatik. Data penelitian berdasar pada data percakapan dari Drama seri Hotaru no Hikari II Episode I. Kemudian penulis meneliti data-data percakapan untuk mengetahui jenis-jenis deiksis persona apa saja yang muncul. kemudian mengelompokkannya ke dalam 3 kategori yaitu deiksis persona orang pertama, deiksis persona orang kedua dan deiksis persona orang ketiga. Lalu menganalisisnya berdasarkan sifat rujukannya dengan teori pragmatik.

\section{Analisis Data}

A. Deiksis Persona Orang Pertama pada Drama seri Hotaru no Hikari II episode I

Dari data percakapan dalam Drama seri Hotaru no Hikari I didapatkan contoh penggunaan deiksis persona orang pertama yang terbagi menjadi dua bagian, yaitu deiksis persona orang pertama tunggal dan deiksis orang pertama jamak, sebagai berikut:

\section{Deiksis Persona Orang Pertama Tunggal}

a. 「俺」 (ore)

Salah satu deiksis persona orang pertama tunggal yang peneliti temukan dalam percakapan dalam drama seri Hotaru no Hikari II episode I adalah "ore". Terdapat 11 contoh penggunaan 
deiksis ini dalam drama seri Hotaru no Hikari II episode I, antara lain adalah sebagai berikut:

Contoh 1 (Seorang laki-laki sedang berbincang dengan dua teman wanitanya di sebuah kafe, Percakapan 1, situasi 1)

$$
\begin{aligned}
& \text { 男 } 1 \quad \text { でさ 俺がバイトし } \\
& \text { てたレンタルビデオ屋の客の女が } \\
& \text { 全然 ビデオを } \\
& \text { 返さないわけよ。で 結局 } \\
& \text { 延滞料金は2万４５８０円。 }
\end{aligned}
$$

Laki-laki 1: Perempuan yang menyewa video di rental video tempat aku bekerja part time tidak pernah mengembalikan videonya. Sampai akhirnya dendanya 2.4580 yen.

$$
\begin{aligned}
& \text { 女 } 1 \text { その女。 マジ!? 何なの? } \\
& \text { その }
\end{aligned}
$$

Perempuan 1: Benarkah? Perempuan macam apa dia?

Dari contoh dalam data diketahui bahwa deiksis "ore" digunakan oleh seorang penutur terhadap petutur yang kedudukannya setara dengannya, yaitu dalam percakapan antara seorang laki-laki dengan dua teman wanitanya, antara Seno Kazuma dengan Amemiya Hotaru yang merupakan teman sekantornya, dan antara Izaki dengan Seno Kazuma dan Amemiya Hotaru yang juga merupakan teman sekantornya.

Selain itu, dalam data pun terlihat pemakaian deiksis "ore" oleh penutur yang lebih tinggi kedudukannya terhadap petutur yang lebih rendah kedudukannya, contohnya dapat dilihat pada percakapan berikut.

Contoh 9 (Takano Seichi berbincang dengan Amemiya Hotaru, percakapan 178, situasi 54)

$$
\begin{aligned}
& \text { 高野誠一： いやいや 俺 } い く \\
& \text { つか知ってる? }
\end{aligned}
$$

Takano Seichi: Tidak tidak kau pikir umurku berapa?
雨宮蛍：年は 関係ないです よ。踊らないとチュ〜しますよ? Amemiya Hotaru: Tidak ada hubungannya dengan umur. Kalau tidak menari akan kucium.

高野誠一：じゃあ 踊らない。

Takano Seichi: Kalau begitu aku tidak akan menari.

Dalam data terdapat pula contoh penggunaan "ore" sebagai deiksis persona orang pertama tunggal, yang dituturkan penutur pada dirinya sendiri, seperti contoh dibawah ini.

Contoh 10 (Izaki berbicara sendiri, percakapan 57, situasi 14)

井崎：俺の憧れ 高野部長。

女には目もくれず 仕事ひと筋の ストイックな男。

夜も走ります!

$$
\text { ちえすと〜! 井崎 今 }
$$

Izaki: Kepala bagian Takano yang aku kagumi, lelaki tangguh yang hanya berpikir soal pekerjaan dan tidak pernah melirik wanita. Siaap.. Izaki hari ini juga akan berlari!

Selain itu, "ore" sebagai deiksis persona orang pertama tunggal dapat digunakan untuk memberikan ketegasan dalam pernyataan yang dituturkan penutur. Hal ini dapat kita lihat pada contoh 11 berikut ini.

Contoh 11 (Takano Seichi berbincang dengan Amemiya Hotaru, percakapan 165 , situasi 51)

雨宮蛍：どうして それ を?

Amemiya Hotaru: Kenapa?

高野誠一： いったろ 私は あの頃とは違う。君のいない 3 年 間私はより深く

$$
\begin{aligned}
& \text { 君のことを考えた。 } \\
& \text { 深く考えたからこ } \\
& \text { のまま なし崩しに } \\
& \text { 君と暮らす気はな } \\
& \text { い。君が帰って来た } \\
& \text { らいうつもりだっ }
\end{aligned}
$$




$$
\begin{aligned}
& \text { た。結婚しよう。こ } \\
& \text { れからの } 2 \text { 人は夫婦 } \\
& \text { だ。君は 一生 俺 } \\
& \text { の女だ。 }
\end{aligned}
$$

Takano Seichi: Sudah kubilang, Aku sudah berbeda dengan waktu dulu. Selama kau tidak ada tiga tahun ini, aku telah memikirkan hubungan denganmu secara lebih mendalam. Karena sudah berpikir lebih dalam, aku tak ingin tinggal denganmu tanpa ikatan seperti selama ini. Aku bermaksud mengatakannya saat kau telah kembali. Ayo kita menikah. Mulai sekarang kita berdua akan menjadi pasangan suami istri. Kau selamanya akan menjadi wanitaku.

Takano Seichi yang pada awal percakapan menggunakan "watashi" sebagai deiksis persona orang pertama tunggal, di akhir percakapan mengubah "watashi" dengan "ore" saat memberi penegasan bahwa Amemiya Hotaru adalah kekasihnya.

Berdasarkan sebelas contoh yang didapatkan dari data, dapat disimpulkan bahwa "ore" merupakan jenis deiksis persona orang pertama tunggal yang banyak digunakan oleh penutur pria terhadap petutur yang kedudukannya setara atau lebih rendah dari penuturnya.

b.「私」”watashi"

Deiksis persona orang pertama tunggal lain yang peneliti temukan dalam percakapan dalam drama seri Hotaru no Hikari II episode I adalah "watashi". Ini merupakan deiksis yang paling banyak digunakan dalam penutur dalam berbagai situasi. Dari dalam data didapatkan 61 contoh penggunaan "watashi" sebagai deiksis persona orang pertama tunggal.

Bila dilihat dari kedudukan penutur dan petutur, penggunaan "watashi" sebagai deiksis persona orang pertama tunggal bersifat netral. Artinya bisa digunakan oleh penutur terhadap petutur yang kedudukannya lebih tinggi, sejajar maupun lebih rendah darinya. Contohnya dapat dilihat pada percakapan berikut.

1. Penggunaan "watashi" sebagai deiksis persona orang pertama tunggal oleh penutur terhadap petutur yang kedudukannya lebih tinggi darinya

Contoh 12 (Wanita 2 sedang berbincang dengan dua orang temannya di sebuah kafe, percakapan 4, situasi 1)

女1:あ 分かった。それ

干物女じやない?

Wanita 1: Ah, aku tahu. Itu Himono Onna bukan?

女 2:

$$
\text { 私も知ってる家でぐうたらしてる○ }
$$

Lでしょ?

Wanita 2: Aku juga tahu, wanita karir yang berleha-leha dirumah bukan?

$$
\begin{aligned}
& \text { 女 } 1: \text { 家では } \\
& \text { 部屋が散らかってても、「まあ } \\
& \text { いっか」って気にしない } \\
& \text { 男っ気は全くなく休日はほと } \\
& \text { じ寝て過ごす。恋愛するより } \\
& \text { 家で寝て } \\
& \text { いたい。それが干物女。 }
\end{aligned}
$$

Wanita 1: Di rumah, walaupun kamar berantakan, dia tidak perduli. Tidak punya kekasih. Hari libur dihabiskan dengan bersantai dan tidur. Daripada brhubungan dengan lelaki, dia lebih memilih tidur di rumah. Itulah Himono onna.

2. Penggunaan "watashi" sebagai 
deiksis persona orang pertama tunggal oleh penutur terhadap petutur yang kedudukannya lebih rendah darinya.

Contoh 13 (Sakuragi Mika berbincang dengan Amemiya Hotaru di ruang kantor mereka, percakapan 22, situasi 8)

桜木美香：あの〜 私も失礼 していいですか?

Sakuragi Mika: Maaf.. Bolehkah saya permisi duluan juga?

雨宮蛍：あなたも 9 時 〜 時の契約?

Amemiya Hotaru: Kamu juga karyawan kontrak dari jam 9- jam 5 ?

\section{桜木美香：いえ 私は社員} なんですけど，もう自分の仕事 終わったんで。

Sakuragi Mika: Tidak, saya karyawan tetap, tapi pekerjaan saya sudah selesai.

3. Penggunaan "watashi" sebagai deiksis persona orang pertama tunggal oleh penutur terhadap petutur yang kedudukannya sejajar dengannya.

Contoh 15 (Yamada Sachiko berbincang dengan Futatsugi di ruang kantor Futatsugi percakapan 32, situasi 10)

山田早智子：っていうか，あな たがしっかりしないからね。と もかくさあの

$$
2 \text { 人が昔一緒に住んで }
$$

たっていうこと知ってんの，あな たと私だけ

としときましょう。

$$
\text { なんだから今は そっ }
$$

Yamada Sachiko: itu karena kamu tidak bisa diandalkan. Tapi, karena yang tahu kalau kedua orang itu pernah tinggal bersama hanya aku dan kamu saja, sekarang kita biarkan saja mereka dulu.

\section{c.「僕」"Boku"}

Deiksis persona pertama tunggal lainnya yang digunakan dalam data drama seri adalah "boku". Deiksis ini digunakan dalam dua situasi percakapan. Yang pertama antara penutur yang kedudukannya lebih tinggi ke penutur yang kedudukannya lebih rendah. Contohnya dapat dilihat pada percakapan berikut.

Contoh 72 (Takano Seichi berbincang dengan pelayan bar di sebuah Bar, percakapan 58, situasi 14)

高野誠一：お待たせ。

Takano Seichi: Maaf telah membuatmu menunggu.

$$
\begin{aligned}
& \text { 浅田小夏 } \quad \\
& \text { 誠一さんよかった。今夜は会えない } \\
& \text { かと思った。 }
\end{aligned}
$$

Asada Konatsu: Syukurlah kau datang Seichi. Aku pikir malam ini kita tidak bisa bertemu.

$$
\begin{aligned}
& \text { 高野誠一 : 僕も } \\
& \text { 同じのください。 }
\end{aligned}
$$

Takano Seichi: Aku minta yang sama

$$
\text { 店員：かしこまりました。 }
$$

Bartender: Baik

$$
\text { 浅田小夏 : 今日は }
$$$$
\text { 忙しかった？ }
$$

Asada Konatsu: Apakah hari ini kau sibuk?

$$
\begin{aligned}
& \text { 高野誠一 : 《まあ } \\
& \text { そうでもないかな》 }
\end{aligned}
$$

Takano Seichi: Tidak juga

"Boku" juga digunakan pada situasi yang berbeda, yaitu antara penutur yang setara kedudukannya. 
Contohnya dapat dilihat pada percakapan berikut.

Contoh $73 \quad$ Futatsugi

berbincang dengan Yamada Sachiko di sebuah bar, percakapan 93, Situasi 24)

$$
\text { ニッ木 : いいの? }
$$

出なくて。

Futatsugi: Tidak apa kau tidak mengangkatnya?

山田早智子：

\section{人生最大の失敗を目}

\section{の前にしてさ}

誰かと話せる気分になると思う？

Yamada Sachiko: Kau pikir aku ingin berbicara dengan orang lain, saat sedang menghadapi kegagalan terbesar dalam hidupku?

$$
\text { ニッ木 }
$$

僕と結婚することが人生最大の失敗

$$
?
$$

Futatsugi: apakah menikah denganku adalah kegagalan terbesar dalam hidupmu?

Dari data yang diperoleh dapat ditarik kesimpulan bahwa "boku" merupakan deiksis persona yang dapat digunakan oleh penutur yang lebih tinggi kedudukannya kepada lawan tutur yang lebih rendah kedudukannya. Dan dapat pula digunakan diantara penutur dan lawan tutur yang memiliki kedudukan yang setara.

d. 「こっち」"kocchi"

Deiksis persona orang pertama tunggal lain yang peneliti temukan dalam data drama seri adalah "kocchi", yang merupakan bentuk non formal dari "kochira". Contoh penggunaannya dapat dilihat pada 2 percakapan di bawah ini.
Contoh 74 (Pemilik perusahaan lampion berbincang dengan Amemiya Hotaru, percakapan 120, Situasi 40)

店主3 ：悪いね〜こっち のミスなのに。

Pemilik Toko 3: Maaf ya.. ini adalah kesalahan kami.

雨宮蛍：的 いいんで す。

Amemiya Hotaru: tidak apa-apa.

Contoh 75 (Takano Seichi berbincang dengan Yamada Sachiko, percakapan 123, Situasi 41)

山田早智子：部長 アンテナ ショップで 15 種類 確保でき ました。

Yamada Sachiko: Bucho, aku telah mendapatkan 15 Jenis dari distributor.

高野誠一：こっちも 渋谷 のビアバーが 譲ってくれるそう だ。

Takano Seichi: Akupun begitu. Sebuah bar di Shibuya dapat menyediakan sebagian untuk kita.

Dari kedua contoh percakapan diatas dapat kita simpulkan bahwa "kocchi" digunakan antara penutur dengan lawan tutur yang kedudukannya setara dengannya. Pada contoh yang pertama, jika dilihat kedudukan secara umum, pemilik toko memiliki kedudukan yang lebih rendah daripada konsumen. Tapi dalam situasi ini, pemilik toko usianya sudah cukup lanjut sementara konsumennya masih muda, sehingga kedudukannya dapat dianggap setara.

2. Deiksis Persona Orang Pertama Jamak

a.「二人」"futari"

Deiksis persona orang pertama jamak yang peneliti dapatkan dari data adalah "futari". Contohnya dapat dilihat pada percakapan berikut ini. 
Contoh 76 (Takano Seichi berbincang dengan Amemiya Hotaru di rumah tempat mereka tinggal bersama, percakapan 56, situasi 13)

高野誠一：私はこのままなし崩 しに君と暮らす気はない。

Takano Seichi: Aku rasa aku tidak ingin terus hidup begini denganmu.

雨宮蛍：は!?

Amemiya Hotaru: Hah?

高野誠一：これからの 2 人につ

いて 後日しっかり話し合お

う。

Takano Seichi: Besok kita bicara serius tentang hubungan kita sekarang 雨宮蛍：え?

Amemiya Hotaru: He?

Dari empat contoh percakapan dalam data dapat diketahui bahwa deiksis "futari" digunakan oleh orang-orang yang sama dalam situasi yang hampir sama. Percakapan-percakapan tersebut dilakukan oleh Takano Seichi dan Amemiya Hotaru di rumah yang mereka tinggali bersama. Dari contoh-contoh tersebut dapat kita simpulkan bahwa "futari" digunakan oleh penutur dan lawan tutur yang memiliki kedudukan setara dalam situasi non formal.

b.「俺ら」"orera"

Deiksis persona orang pertama jamak lainnya yang peneliti dapatkan dari data adalah "orera". Contohnya dapat dilihat pada percakapan dibawah ini. Contoh 80 (Umeda berbincang sambil makan siang bersama dengan Amemiya Hotaru Chikurin, Seno Kazuma, Makoto, Matsu Kouji, Umeda, dan Sakuragi Chika di sebuah restoran, percakapan 62, situasi 16)

梅田： じゃ 俺らも行く? いいの? お金。

Umeda: Kalau begitu kita juga pergi sekarang? Tidak apa-apa? Uangnya bagaimana?
真菜 : : やおごってくれ

るんじやないんですか? 普通そう

でしょ。

Makoto: Tidak. Kita ditraktir kan?

Biasanya kan seperti itu.

Dari contoh situasi dapat kita simpulkan bahwa "orera" digunakan oleh penutur dan lawan tutur yang memiliki kedudukan setara dalam situasi non formal.

c.「私達」”watashitachi”

Deiksis persona orang pertama jamak lainnya yang peneliti dapatkan dari data adalah "watashitachi". Contohnya dapat dilihat pada percakapan berikut ini.

Contoh 81 (Amemiya Hotaru berbincang dengan Takano Seichi, percakapan 174, Situasi 53)

雨宮蛍：あの 浅田小夏さ んとかいうキレイな人は?

Amemiya Hotaru: Bagaimana dengan wanita cantik yang bernama Asada Konatsu?

高野誠一：彼女は 君には関 係ない。

Takano Seichi: Dia tidak ada hubungannya denganmu.

雨宮蛍：関係ありますよ。 どういう人か聞かせてください。

だから。

$$
\text { 私達 結婚寸るん }
$$

Amemiya Hotaru: ada hubungannya. Beritahu aku dia siapa. Kita kan akan menikah.

Dari percakapan diatas dapat kita simpulkan bahwa "watashitachi" digunakan antara penutur dan lawan tutur yang memiliki kedudukan atau tingkat sosial yang setara.

B. Deiksis Persona Orang Kedua pada Drama seri Hotaru no Hikari II episode I

Hasil analisis data percakapan dari Drama seri Hotaru no Hikari I didapat contoh penggunaan deiksis persona 
orang kedua yang terbagi dua bagian, yaitu deiksis persona orang kedua tunggal dan deiksis orang kedua jamak, sebagai berikut:

\section{Deiksis Persona Orang Kedua Tunggal}

a. 「君」"kimi"

Deiksis persona orang kedua tunggal yang peneliti dapatkan dari data adalah "kimi". Deiksis ini digunakan dalam 24 situasi percakapan. Dari data yang terkumpul dapat diketahui bahwa "kimi" banyak digunakan oleh penutur yang memiliki hubungan lebih tinggi dan setara dengan petuturnya. Contohnya dapat dilihat pada percakapan berikut ini.

Contoh 82 (Futatsugi berbicara dengan Amemiya Hotaru di ruang kantor bagian personalia, percakapan 13, Situasi 4)

雨宮蛍：二ツ木さん お久 しぶりです。

Amemiya Hotaru: Lama tidak bertemu ya Futatsugi.

二ツ木：偉いね 今日 着い
たばっかりなのに。はい、これ新
しい社員証。

Futatsugi: hebat ya, padahal kau baru saja tiba di Jepang. Ini kartu tanda pegawaimu yang baru.

雨宮蛍：ありがとうござい ます。

Amemiya Hotaru: Terima kasih

二ツ木：君がいない間ね、

随分と体制変わったんだよね。以 前いたメンツ

$$
\text { くなったし。 もほとんど いな }
$$

Futatsugi: selama kau pergi, perusahaan cukup berubah. Orang yang kau kenal sebelumnya kebanyakan sudah tidak ada.

b.「あんた」”Anta”

"Anta" yang merupakan bentuk non formal dari anata, adalah deiksis persona kedua tunggal yang peneliti temukan dari data penelitian. Deiksis ini digunakan oleh penutur kepada petutur yang memiliki hubungan setara dengannya. Contohnya dapat dilihat pada percakapan berikut.

Contoh 107 (Seno Kazuma berbicara dengan Amemiya Hotaru, percakapan 16, Situasi 5)

瀬乃和馬：あんたさ, 嵐山のド キュン子に似てんね。

Seno Kazuma: kau ini mirip dengan Dokyunko dari Arashima ya 雨宮蛍：嵐山のドキュン 子?

Amemiya Hotaru: Dokyunko dari Arashima?

c.「あなた」"Anata"

Contoh Deiksis Persona orang kedua tunggal lain yang peneliti temukan dari data adalah "anata". "Anata" digunakan oleh penutur kepada petutur yang setara dengannya. Jika dilihat dari situasinya, anata lebih banyak digunakan diantara penutur dan petutur yang tidak memiliki hubungan akrab atau intim. Contohnya dapat dilihat pada percakapan berikut.

Contoh 113 (Amemiya Hotaru berbincang dengan Sakuragi Mika di ruang kantor mereka, percakapan 23 , Situasi 8)

桜木美香：あの〜 私も失礼
していいですか?

Sakuragi Chika: Maaf.. bolehkah aku permisi duluan juga?
雨宮蛍：あなたも 9 時 〜 時の契約?

Amemiya Hotaru: Kau karyawan kontrak dari jam 9 sampai jam 5 juga? 桜木美香：いえ 私は社員 なんですけど，もう自分の仕事 終 わったんで。

Sakuragi Chika: Bukan, aku pegawai tetap sih, tapi pekerjaanku sudah selesai. 
d. 「お前」”Omae"

Deiksis persona orang kedua tunggal lain yang peneliti temukan adalah "omae". Deiksis ini digunakan dalam dua situasi dalam data penelitian. Dari contoh penggunaannnya dapat disimpulkan bahwa "omae" digunakan oleh penutur kepada petutur yang memiliki kedudukan setara dengannya dan keduanya memiliki hubungan yang dekat atau akrab. Contohnya dapat dilihat pada percakapan berikut ini.

Contoh 119 (Takano Seichi berbincang dengan Amemiya Hotaru di rumah tempat mereka tinggal bersama, percakapan 48, Situasi 12) 雨宮蛍：でもでもでも そのメールも 最初は 週に 3 日 だったのに

$$
\text { だんだん少なくな }
$$

っ 。

Amemiya Hotaru: Tapi..tapi..tapi.. Email itu pun hanya seminggu tiga kali dan semakin lama semakin jarang 高野誠一：だって返事が来な いんだもん。全然 来ないんだも 几!

Takano Seichi: Karena tidak ada jawaban. Sama sekali tidak ada jawaban!

雨宮蛍：大丈夫ですよ。

Amemiya Hotaru: Tidak apa-apa

高野誠一：何が大丈夫なんだ よ!揃が励ますな！

Takano Seichi: apanya yang tidak apa-apa! Kau tidak usah menghiburku

2. Deiksis Persona Orang Kedua Jamak

a.「皆様」"minnasama"

Deiksis persona orang kedua jamak yang digunakan dalam data penelitian adalah "minnasama". Deiksis ini digunakan oleh penutur yang memiliki tingkat sosial lebih rendah dari petuturnya. Contohnya dapat dilihat pada percakapan berikut.
Contoh 121 (Pramugari memberikan pengumuman saat penerbangan berlangsung, percakapan 8, Situasi 3)

(機内アナウンス)

皆様 着陸体勢に入りました。シ 一トベルトを緩みのないようしっ かりお締めください。この先飛 行機をお降りになるまで電子機器 類の電源をお切りください。

(Pengumumaan di dalam pesawat)

Para penumpang, kita sebentar lagi akan mendarat. Tolong tegakkan posisi kursi anda dan pastikan sabuk pengaman anda terpasang dengan baik. Tolong matikan semua barang elektronik sampai kita mendarat dengan selamat.

b.「皆さん」"Minnasan"

Deiksis persona orang kedua jamak yang digunakan dalam data penelitian adalah "minnasan". Deiksis ini digunakan oleh penutur yang memiliki tingkat sosial setara atau lebih tinggi dari petuturnya. Contohnya dapat dilihat pada percakapan berikut.

Contoh 122 (Yamada Sachiko berbicara dalam rapat dengan Amemiya Hotaru, Takano Seichi, Izaki, Seno Kazuma, dan pegawai lainnya di ruang rapat, percakapan 19, Situasi 6)

山田早智子: 以上です。皆さ ん急ぎでお願いします。

Yamada Sachiko: Rapatnya selesai. Semuanya harap bergegas.

\section{Deiksis persona Orang Ketiga pada Drama seri Hotaru no Hikari II episode I}

Hasil analisis data percakapan dari Drama seri Hotaru no Hikari I didapat contoh penggunaan deiksis persona orang ketiga yang terbagi dua bagian, yaitu deiksis persona orang ketiga tunggal dan deiksis orang ketiga jamak, sebagai berikut: 


\section{Deiksis Persona Orang Ketiga Tunggal}

a.「その女」"sonoonna"

Deiksis persona orang ketiga tunggal yang digunakan dalam data penelitian adalah "sono onna". Deiksis ini digunakan oleh penutur yang memiliki tingkat sosial setara dengan petuturnya, dan keduanya tidak memiliki hubungan yang akrab dengan orang ketiga yang mereka bicarakan. Contohnya dapat dilihat pada percakapan berikut.

Contoh 124 (Wanita 1 sedang berbincang dengan dua orang temannya di sebuah kafe., percakapan 2, situasi 1)

男 1 : でさ 俺がバイトして たレンタルビデオ屋の客の女が 全然 ビデオを

返さないわけよ。で

結局延帯料金は 2 万 4580

円。

Laki-laki 1: Wanita yang menyewa video di rental video tempat aku part time tidak pernah mengembalikan videonya. Sampai akhirnya dendanya 2.4580 yen.

女 1 : マジ!? 何なの? そ の女。

Perempuan 1: Benarkah? Perempuan macam apa dia?

b.「それ」"sore"

Deiksis persona orang ketiga tunggal yang digunakan dalam data penelitian adalah "sore". Deiksis ini digunakan oleh penutur yang memiliki tingkat sosial setara dengan petuturnya, dan keduanya tidak memiliki hubungan yang akrab dengan orang ketiga yang mereka bicarakan. Contohnya dapat dilihat pada percakapan berikut.

c.「そんな女」"sonnaonna"

Deiksis persona orang ketiga tunggal yang digunakan dalam data penelitian adalah "sonna onna". Deiksis ini digunakan oleh penutur yang memiliki tingkat sosial setara dengan petuturnya, dan keduanya tidak memiliki hubungan yang akrab dengan orang ketiga yang mereka bicarakan. Contohnya dapat dilihat pada percakapan berikut.

Contoh 127 (Laki-laki 1 sedang berbincang dengan dua orang teman wanitanya di sebuah kafe, percakapan 7 , situasi 1)

男 1 : 俺 ぜってえそんな

女付き合いたくねえわ。

Laki-laki 1 : Aku benar-benar tidak ingin bertemu dengan perempuan seperti itu.

$$
\text { 一同 : だよね〜！ }
$$

Semua: Iya ya...!

d.「こんなの」"konnano"

Deiksis persona orang ketiga tunggal yang digunakan dalam data penelitian adalah "konnano". Deiksis ini digunakan oleh penutur yang memiliki tingkat sosial setara dengan petuturnya, dan dia memiliki hubungan yang akrab dengan orang ketiga yang dibicarakan. Contohnya dapat dilihat pada percakapan berikut. Contoh 128 (Futatsugi berbicara dengan Amemiya Hotaru tentang Seno Kazuma yang kebetulan datang ke ruang kantor bagian personalia, percakapan 14, situasi 4)

瀬乃和馬 : 瀬乃で〜す。

Seno Kazuma: Aku Seno.

$$
\begin{aligned}
& \text { 二ツ木 : 二ツ木で〜す。ほら、 } \\
& \text { こんなのも 以前 いなかっただ } \\
& \text { ろ。 こいつプランナーの瀬乃 }
\end{aligned}
$$

君。人事部に何の用?

Futatsugi: Aku Futatsugi. Lihat Dia sebelumnya tidak ada kan. Dia Seno dari bagian perencanaan. Ada perlu apa di bagian personalia?

e.「こいつ」"koitsu"

Deiksis persona orang ketiga tunggal yang digunakan dalam data penelitian adalah "koitsu". Deiksis ini 
digunakan oleh penutur yang memiliki tingkat sosial setara dengan petuturnya, dan dia memiliki hubungan yang akrab dengan orang ketiga yang dibicarakan. Contohnya dapat dilihat pada percakapan berikut. Contoh 129 (Futatsugi berbicara dengan Amemiya Hotaru tentang Seno Kazuma yang kebetulan datang ke ruang kantor bagian personalia, percakapan 15 , situasi 4)

瀬乃和馬 : 瀬乃で〜す。

Seno Kazuma: Aku Seno.

$$
\begin{gathered}
\text { 二ツ木 : 二ツ木で〜す。 } \\
\text { ほら、こんなのも } \\
\text { 以前 いなかっただろ。 } \\
\text { こいつプランナーの瀬乃 }
\end{gathered}
$$

君。人事部に何の用?

Futatsugi: Aku Futatsugi. Lihat Dia sebelumnya tidak ada kan. Dia Seno dari bagian perencanaan. Ada perlu apa di bagian personalia?

f.「あの人」"Ano hito"

Deiksis persona orang ketiga tunggal yang digunakan dalam data penelitian adalah "ano hito". Deiksis ini digunakan oleh penutur yang memiliki tingkat sosial setara dengan petuturnya, dan dia memiliki hubungan yang akrab dengan orang ketiga yang dibicarakan. Contohnya dapat dilihat pada percakapan berikut. Contoh 129 (Seno Kazuma berbincang dengan Amemiya Hotaru, percakapan 71, situasi 19)

瀬乃和馬：何だ? あの人。 気にしてんの? 結局 金は 俺が 払ったこと。

Seno Kazuma: Kenapa dia? Apa kau risau karena akhirnya aku yang membayar?

雨宮蛍：あ... すいません でした。

Amemiya Hotaru: maafkan aku.

g.「その人」"sono hito"

Deiksis persona orang ketiga tunggal yang digunakan dalam data penelitian adalah "sonohito". Deiksis ini digunakan oleh penutur yang memiliki tingkat sosial setara dengan petuturnya, dan dia tidak memiliki hubungan yang akrab dengan orang ketiga yang dibicarakan. Contohnya dapat dilihat pada percakapan berikut. Contoh 130 (Amemiya Hotaru berbincang dengan Takano Seichi di rumah dimana mereka tinggal bersama, percakapan 82, situasi 22)

雨宮蛍：また お出かけで すか?

Amemiya Hotaru: Apa kau akan keluar lagi?

高野誠一：ああ。

Takano Seichi: iya.

雨宮蛍：昨夜 会ってた 人?

Amemiya Hotaru: Dengan orang yang kau temui semalam?

高野誠一：ああ。

Takano Seichi: Iya.

雨宮蛍： その人って どう いう...?

Amemiya Hotaru: Siapa orang itu?

高野誠一：君の知らない人 だ。

Takano Seichi: Orang yang tidak kau kenal.

h. 「彼」"kare"

Deiksis persona orang ketiga tunggal yang digunakan dalam data penelitian adalah "kare". Deiksis ini digunakan oleh penutur yang memiliki tingkat sosial setara dengan petuturnya, dan dia memiliki hubungan yang akrab dengan orang ketiga yang dibicarakan. Contohnya dapat dilihat pada percakapan berikut.

Contoh 131 (Takano Seichi berbincang dengan Amemiya Hotaru, percakapan 156, situasi 51) 雨宮蛍：じゃあ 瀬乃さん はアザラシに そっくりな女 と 朝まで一緒に? 
Amemiya Hotaru: Jadi Seno sampai pagi bersama dengan wanita yang mirip dengan anjing laut?

高野誠一：彼加らしたら水 難事故だ。ま 君のほうは 泥酔 して目覚めた時に

$$
\text { 隣に男がいて一瞬 }
$$

喜んだに違いないが。

Takano Seichi: Mungkin untuknya itu seperti penyelamatan binatang laut liar. Sedang untukmu pada saat sadar dari mabukmu, aku yakin kau senang kau telah tidur di sebelah seorang laik-laki.

i.「彼女」"kanojo"

Deiksis persona orang ketiga tunggal yang digunakan dalam data penelitian adalah "kanojo". Deiksis ini digunakan oleh penutur yang memiliki tingkat sosial setara dengan petuturnya, dan dia memiliki hubungan yang akrab dengan orang ketiga yang dibicarakan. Contohnya dapat dilihat pada percakapan berikut. Contoh 132 (Takano Seichi berbincang dengan Amemiya Hotaru, percakapan 172, situasi 53) 雨宮蛍： あの 浅田小夏さ んとかいうキレイな人は?

Amemiya Hotaru: Siapa Wanita cantik bernama Asada Konatsu itu? 高野誠一：彼女は 君には関 係ない。

Takano Seichi: Dia tidak ada hubungannya denganmu

雨宮蛍：関係ありますよ。

どういう人か＼cjkstart聞かせてくださ

い。私達 結婚するん

$$
\text { だから。 }
$$

Amemiya Hotaru: Ada hubungannya. Tolong Beritahu aku siapa dia. Kita kan akan menikah.

2. Deiksis Persona Orang Ketiga Jamak

a.「あの 2 人」”Ano futari"
Deiksis persona orang ketiga jamak yang digunakan dalam data penelitian adalah "ano futari". Deiksis ini digunakan oleh penutur yang memiliki tingkat sosial setara dengan petuturnya, dan dia memiliki hubungan yang akrab dengan orang ketiga yang dibicarakan. Contohnya dapat dilihat pada contoh percakapan berikut.

Contoh 133 (Futatsugi berbincang dengan Yamada Sachiko di ruang kantor Futatsugi (bagian personalia), percakapan 25, situasi 10)

山田早智子 : 何 見てんの?

Yamada Sachiko: Kau sedang melihat apa?

二ツ木 $\quad$ : いや… あの 2

人どうなんだろ?

Futatsugi: Tidak.. Kedua orang itu bagaimana ya?

山田早智子：部長と蛍?

Yamada Sachiko: Kepala bagian dan Amemiya?

\section{KESIMPULAN}

1. Deiksis persona yang terdapat pada Drama seri Hotaru no Hikari II episode I

Setelah peneliti mengadakan penelitian dengan objek berupa percakapan yang mengandung deiksis dalam drama seri Hotaru no Hikari II episode I, dapat diketahui bahwa deiksis persona yang digunakan meliputi 3 kategori deiksis yaitu deiksis persona orang pertama, deiksis persona orang kedua dan deiksis persona orang ketiga.

a. Deiksis Persona Orang Pertama Deiksis persona orang pertama dibagi menjadi dua jenis yaitu, deiksis persona orang pertama tunggal dan deiksis persona orang pertama jamak.

Deiksis persona orang pertama tunggal yang digunakan dalam 
data adalah 「俺」 "ore” (11 contoh), 「私」”watashi” (61 contoh), 「僕」"boku" (2 contoh), dan 「こっち」"kocchi" (2 contoh).

Sedangkan deiksis persona orang pertama jamak yang digunakan dalam data adalah 「二 人」"futari" (4 contoh), 「俺 ら」”orera" (1 contoh), dan「私 達」“watashitachi” (1 contoh),

b. Deiksis Persona Orang Kedua

Deiksis persona orang kedua dibagi menjadi dua jenis yaitu, deiksis persona orang kedua tunggal dan deiksis persona orang kedua jamak.

Deiksis persona orang kedua tunggal yang digunakan dalam data adalah「君」 "kimi” (24 contoh),「あんた」 “Anta” (6 contoh),「あなた」 “Anata” (6 contoh), dan 「お前」"Omae" (2 contoh).

Sedangkan deiksis persona orang kedua jamak yang digunakan dalam data adalah 「皆様」 “minnasama” ( 1 contoh), dan「皆 さん」 "Minnasan" (2 contoh).

c. Deiksis Persona Orang Ketiga Tunggal

Deiksis persona orang ketiga dibagi menjadi dua jenis yaitu, deiksis persona orang ketiga tunggal dan deiksis persona orang ketiga jamak.

Deiksis persona orang ketiga tunggal yang digunakan dalam data adalah 「その女」 "sono hito" (1 contoh),「それ」 “sore” (2 contoh), 「そんな女」 “sonna onna" (1 contoh), 「こんなの」 "konnano" (1 contoh),「こいつ」 "koitsu” (1 contoh),「あの人」 “ano hito" (1 contoh), 「その
人」 "sono hito" (1 contoh), 「彼」 “kare” (1 contoh), dan 「彼女」“kanojo" (1 contoh).

Sedangkan Deiksis persona orang ketiga jamak yang digunakan dalam data adalah 「あの 2 人」 "ano futari” ( 2 contoh).

\section{Status Sosial sebagai Faktor Penentu Pemilihan Deiksis}

Dari hasil analisis data diketahui bahwa penggunaan deiksis pada percakapan dalam drama seri Hotaru no Hikari II episode I ditentukan oleh status sosial penutur dan petuturnya. Hal ini terlihat dari adanya perbedaan pilihan deiksis yang digunakan oleh penutur yang memiliki status sosial lebih tinggi, setara atau lebih rendah dari petuturnya.

\section{a. Deiksis Persona Orang Pertama} Tunggal

1)「俺」"ore"

「俺」 "ore" merupakan jenis deiksis persona orang pertama tunggal yang banyak digunakan oleh penutur kepada petutur yang kedudukannya setara atau lebih rendah dari penuturnya.

Selain itu, 「俺」 "ore" sebagai deiksis persona orang pertama tunggal dapat digunakan untuk memberikan ketegasan dalam pernyataan yang dituturkan penutur.

2)「私」"watashi"

Bila dilihat dari kedudukan penutur dan petutur, penggunaan私"watashi”

sebagai deiksis persona orang pertama tunggal bersifat netral. Artinya bisa digunakan oleh penutur terhadap petutur yang kedudukannya lebih tinggi, setara maupun lebih rendah darinya.

3)「僕」 "boku” 
"Boku" merupakan deiksis persona yang dapat digunakan oleh penutur yang lebih tinggi kedudukannya kepada lawan tutur yang lebih rendah kedudukannya. Dan dapat pula digunakan diantara penutur dan lawan tutur yang memiliki kedudukan yang setara.

4)「こっち」"kocchi"

"Kocchi" digunakan antara penutur dengan lawan tutur yang kedudukannya setara dengannya.

b. Deiksis Persona Orang Pertama Jamak

1)「二人」 “futari”

"Futari" digunakan oleh penutur dan lawan tutur yang memiliki kedudukan setara dalam situasi non formal.

2)「俺ら」"orera"

Orera digunakan oleh penutur dan lawan tutur yang memiliki kedudukan setara dalam situasi non formal.

3)「私達」“watashitachi” "Watashitachi" digunakan antara penutur dan lawan tutur yang memiliki kedudukan atau tingkat sosial yang setara.

c. Deiksis Persona Orang Kedua Tunggal

1)「君」"kimi"

"Kimi" banyak digunakan oleh penutur yang memiliki hubungan lebih tinggi dan setara dengan petuturnya.

2)「あんた」“Anta” "Anta" yang merupakan bentuk non formal dari anata, digunakan oleh penutur kepada petutur yang memiliki hubungan setara dengannya.

3)「あなた」“Anata”

"Anata" digunakan oleh penutur kepada petutur yang setara dengannya. Jika dilihat dari situasinya, anata lebih banyak digunakan diantara penutur dan petutur yang tidak memiliki hubungan akrab atau intim.

4)「お前」 “Omae”

"Omae" digunakan oleh penutur kepada petutur yang memiliki kedudukan setara dengannya dan keduanya memiliki hubungan yang dekat atau akrab.

d. Deiksis Persona Orang Kedua Jamak

1)「皆様」 “minnasama”

Deiksis ini digunakan oleh penutur yang memiliki tingkat sosial lebih rendah dari petuturnya.

2)「皆さん」"Minnasan"

Deiksis ini digunakan oleh penutur yang memiliki tingkat sosial setara atau lebih tinggi dari petuturnya.

e. Deiksis Persona Orang Ketiga Tunggal

1)「その女」 "sono hito"

Deiksis ini digunakan oleh penutur yang memiliki tingkat sosial setara dengan petuturnya, dan keduanya tidak memiliki hubungan yang akrab dengan orang ketiga yang mereka bicarakan.

2)「それ」"sore”

Deiksis ini digunakan oleh penutur yang memiliki tingkat sosial setara dengan petuturnya, dan keduanya tidak memiliki hubungan yang akrab dengan orang ketiga yang mereka bicarakan.

3)「そんな女」“sonna onna”

Deiksis ini digunakan oleh penutur yang memiliki tingkat sosial setara dengan petuturnya, 
dan keduanya tidak memiliki hubungan yang akrab dengan orang ketiga yang mereka bicarakan.

4)「こんなの」 "konnano"

Deiksis ini digunakan oleh penutur yang memiliki tingkat sosial setara dengan petuturnya, dan dia memiliki hubungan yang akrab dengan orang ketiga yang dibicarakan.

5)「こいつ」"koitsu"

Deiksis ini digunakan oleh penutur yang memiliki tingkat sosial setara dengan petuturnya, dan dia memiliki hubungan yang akrab dengan orang ketiga yang dibicarakan.

6)「あの人」 “ano hito”

Deiksis ini digunakan oleh penutur yang memiliki tingkat sosial setara dengan petuturnya, dan dia memiliki hubungan yang akrab dengan orang ketiga yang dibicarakan.

7)「その人」 "sono hito"

Deiksis ini digunakan oleh penutur yang memiliki tingkat sosial setara dengan petuturnya, dan dia tidak memiliki hubungan yang akrab dengan orang ketiga yang dibicarakan.

8)「彼」 “kare”

Deiksis ini digunakan oleh penutur yang memiliki tingkat sosial setara dengan petuturnya, dan dia memiliki hubungan yang akrab dengan orang ketiga yang dibicarakan.

9)「彼女」“kanojo”

Deiksis ini digunakan oleh penutur yang memiliki tingkat sosial setara dengan petuturnya, dan dia memiliki hubungan yang akrab dengan orang ketiga yang dibicarakan.

\section{f. Deiksis Persona Orang Ketiga Jamak}

1)「あの 2 人」 “ano futari”

Deiksis ini digunakan oleh penutur yang memiliki tingkat sosial setara dengan petuturnya, dan dia memiliki hubungan yang akrab dengan orang ketiga yang dibicarakan.

\section{DAFTAR PUSTAKA}

Edizal. 2001. Tutur Kata Manusia Jepang. Padang: Kayu Pasak.

Djajasudarma, Fatimah. 1994. Wacana. Rosda Karya: Bandung

Purwo, Bambang K. 1990. Pragmatik dan Pengajaran Bahasa. Yogyakarta

Leech, Geoffrey N. 1983. The Principle of Pragmatics. Longman: London

Levinson, Stephen C. 1978. Pragmatics. Cambridge: Cambridge University Press

Lyons, John. 1977. Introduction to Theoritical Linguistics. Cambridge: Cambridge University Press

Nababan. 1987. Ilmu Pragmatik: Teori dan Penerapannya. Jakarta: Departemen Pendidikan dan Kebudayaan

Sudaryat 2008. Makna dalam Wacana. Bandung: Yrama Widya. 